DOI: $10.17805 /$ trudy.2018.1.4

\title{
РАЗРАБОТКА ПРОБЛЕМЫ ПСИХОМОТОРИКИ НА КАФЕДРЕ ОБЩЕЙ ПСИХОЛОГИИ И ИСТОРИИ ПСИХОЛОГИИ МОСКОВСКОГО ГУМАНИТАРНОГО УНИВЕРСИТЕТА
}

\author{
Н. Е. Коренкова \\ Московский гуманитарный университет
}

Аннотация: В статье представлен обзор психологических исследований, посвященных изучению психомоторики человека, которые проводились на факультете психологии, педагогики и социологии Московского гуманитарного университета.

Ключевые слова: психомоторика; психомоторный профиль; графологический анализ; графическая деятельность; психомоторное развитие; моторная одаренность; психомоторная диагностика; Московский гуманитарный университет

\section{DEVELOPMENT OF THE PSYCHOMOTORICS ISSUE AT THE DEPARTMENT OF GENERAL PSYCHOLOGY AND THE HISTORY OF PSYCHOLOGY OF MOSCOW UNIVERSITY FOR THE HUMANITIES}

\author{
N. E. Korenkova \\ Moscow University for the Humanities
}

Abstract: The article presents a review of psychological studies devoted to the study of human psychomotorics, which were conducted at the Faculty of Psychology, Pedagogy and Social Science of Moscow University for the Humanities.

Keywords: psychomotorics; psychomotor profile; graphological analysis; graphical activity; psychomotor development; motor aptitude; psychomotor diagnostics; Moscow University for the Humanities

Расширение междисциплинарных исследований, направленных на комплексное, всестороннее и многоаспектное рассмотрение психических феноменов, необходимость интеграции знаний смежных с психологией дисциплин, определение и уточнение исходных теоретических и методологических положений, лежащих в основе современного комплексного человекознания, потребность в повышении достоверности и точности психодиагностического инструментария - можно обозначить в качестве условий, обусловливающих актуальность исследований в области психомоторики. Изучение психомоторики является актуальным как для дальнейшего развития теории психологии, так и для ее прак- 
тических приложений в различных областях общественной практики.

Разработка проблемы психомоторики человека на кафедре общей психологии и истории психологии Московского гуманитарного университета имеет уже достаточно продолжительную историю (почти два десятка лет) и реализуется в рамках преподавания курсов «Развитие и диагностика психомоторики», «Психология спорта». Данная статья представляет собой обобщение материалов, полученных самим автором, а также результатов работ студентов и магистрантов, выполненных под его руководством.

Началом данного направления исследований на кафедре общей психологии и истории психологии послужила кандидатская диссертация Н. Е. Коренковой (Коренкова, 2000) под научным руководством Ю. Н. Олейника. Исследование было направлено на выявление и описание типологических особенностей структуры психомоторных показателей человека в форме индивидуальных психомоторных профилей и изучение их взаимосвязей с индивидными, личностными и субъектно-деятельностными характеристиками человека как интегральной индивидуальности. В данной работе впервые был проведен историко-теоретический анализ взглядов ученых на определение и ключевые проблемы психомоторики, предложена авторская периодизация истории разработки проблемы; рассмотрены особенности психомоторной организации человека в структуре интегральной индивидуальности; эмпирически выявлены общая структура психомоторики юношей и девушек 15-17 лет, а также типологические особенности их психомоторной организации, дан психологический портрет подростков с различными психомоторными профилями; эмпирически доказана взаимосвязь психомоторных характеристик юношей и девушек с их индивидно-личностными свойствами и характеристиками человека как субъекта деятельности; показана возможность эмпирического определения типа индивидуального психомоторного профиля (ИПП) юношей и девушек (Коренкова, 1999, 2005, 2006, 2007).

Дальнейшие исследования автора разворачивались в русле расширения и уточнения полученных ранее данных, а также рассмотрения различных теоретических и прикладных аспектов феномена психомоторики. Так, в ряде исследований поднимается проблема сохранения психологической безопасности специалиста, осуществляющего свою деятельность в особых условиях. Обеспечение специалистом собственной психологической безопасности рассматривается в качестве одного из главных условий сохранения профессионального здоровья, минимизации физического и психического травматизма. Обосновывается необходимость изучения базовых механизмов психомоторики человека в целях формирования у специалистов необходимых знаний и навыков для реализации психологически безопасного поведения (Коренкова, 2008, 2012, 2017).

Ряд студенческих дипломных и бакалаврских работ, выполненных под руководством автора, был посвящен изучению уровня развития двигательных умений и отдельных компонентов моторики у детей и подростков. Проблема моторной одаренности детей и подростков изучалась Е. В. Медведевой в аспекте выявления особенностей психомоторного и умственного развития у детей младшего школьного возраста (Медведева, 2016), взаимосвязи психомоторики со стилем 
реагирования личности на фрустрацию Т. И. Киселевой (Киселева, 2006), особенностей индивидно-личностных характеристик школьников с разными функциональными состояниями Л. А. Савиной (Савина, 2009), взаимосвязи адаптивности и психомоторных показателей подростков; а также соотношения психомоторики с телосложением и характером Н. А. Толкачевой (Толкачева, 2017).

Интересная серия студенческих работ в разные годы была посвящена графологическому анализу почерка. Так, графологические характеристики исследовались Л. В. Калининой во взаимосвязях с рядом темпераментальных и личностных свойств (Калинина, 2005), с уровнем развития интеллекта - Е. И. Зотиной (Зотина, 2003), акцентуаций характера и нейродинамическими особенностями Е. В. Коршуновой (Коршунова, 2012).

В целях формирования представления о взаимосвязи психического расстройства и почерка человека были проведены исследования на базе дневного стационара и медико-реабилитационного отделения Психиатрической клинической больницы №1 им. Н. А. Алексеева. Результаты исследований отражены в бакалаврских работах А. А. Бекетовой «Графологические особенности почерка лиц с расстройствами психического здоровья» (Бекетова, 2017) и А. И. Бекетова «Использование графологического анализа почерка для оценки динамики признаков агрессии у больных шизофренией» (Бекетов, 2017). В этих исследованиях выявлены значимые отличия почерка лиц с органическими поражениями головного мозга от почерка психически здоровых лиц. Наиболее информативными графологическими показателями оказались: размер букв, ширина и непрерывность почерка. Специфику почерка лиц с шизофренией могут отражать: характерное расположение текста на листе, а также беглость почерка, его вычурность, оригинальность, витиеватость. Также, в данных работах показана динамика графически проявляемых признаков агрессии у пациентов, страдающих шизофренией, при переходе из психоза в состояние ремиссии.

Рассмотрение метода графологического анализа как объективной диагностической методики имеет большие перспективы в современной психологии. Умение выявлять особенности психического развития, а также наличие расстройств психиатрического спектра средствами графологии, может применяться во многих областях деятельности практического психолога, от профориентации и трудовой экспертизы до коррекционной работы в нейропсихологии.

Интереснейшее исследование под нашим научным руководством на базе психофизиологической лаборатории и с непосредственным участием проф. В. М. Звоникова было проведено магистранткой кафедры общей психологии и истории психологии Е. А. Захаревской (Захаревская, 2015). Исследование было направлено на выявление и описание взаимосвязей между показателями моторной активности рук с индивидно-личностными особенностями человека при выполнении сложнокоординированной графической деятельности в моделируемых условиях. В работе был проведен эксперимент с использованием специфической аппаратуры, в том числе, психофизиологического тестирования. В рамках многоэтапного исследования была разработана моторная проба для измерения моторной активности рук при выполнении сложнокоординированной графической 
деятельности в моделируемых условиях (в состоянии покоя и под воздействием дополнительного сбивающего фактора). В результате исследования были установлены взаимосвязи между индивидно-личностными особенностями человека и показателями моторной активности рук при выполнении сложнокоординированной графической деятельности. Выявлена специфика индивидуально-психологических характеристик и моторных показателей в группах с разными типологическими особенностями. Доказано, что психомоторные характеристики могут выступать в качестве объективных индикаторов психической деятельности человека, психических свойств и состояний личности.

Научная работа Е. А. Захаревской на тему «Взаимосвязь индивидно-личностных особенностей человека с показателями моторной активности рук» по итогам конкурса студенческих научных работ Союза негосударственных вузов Москвы и Московской области за 2016 г. была удостоена золотой медали.

Научные работы, связанные с изучением проблематики психомоторной сферы человека в отечественной психологии, очень немногочисленны и роль психомоторных методов в психодиагностике до сих пор остается недооцененной. Таким образом, несомненным вкладом наших исследований в развитие теории и практики психологии является обозначение роли и психодиагностической значимости характеристик психомоторики в структуре целостной индивидуальности человека.

В целом, подводя итоги обзора, можно обозначить перспективы дальнейших исследований проблемы психомоторики в сторону расширения и объективизации психомоторной диагностики как психодиагностического инструментария индивидуально-психологических особенностей человека. Особое практическое значение данное положение приобретает в системе психологического обеспечения профессиональной деятельности, психологической коррекции, реабилитации и т. д.

\section{СПИСОК ЛИТЕРАТУРЫ}

Коренкова, Н. Е. (1999) К проблеме периодизации исследований психомоторики // Формирование и развитие личности: теоретические и методологические проблемы. М. : Институт молодежи. С. 34-40.

Коренкова, Н. Е. (2000) Психомоторика в структуре интегральной индивидуальности человека: Период ранней юности : автореф. дис.... канд. психол. наук. М. $27 \mathrm{c}$.

Коренкова, Н. Е. (2005) Психомоторика в структуре интегральной индивидуальности человека : учеб. пособие. Моск. гуманитар. ун-т, Каф. общ. психологии и истории психологии. Москва, 2005. 164 с.

Коренкова, Н. Е. (2006) Психомоторика в структуре интегральной индивидуальности человека // Психологический журнал. Т. 27. № 1. С. 54-66.

Коренкова, Н. Е. (2007) Типологические особенности психомоторной организации человека // Учебные записки: вопросы экономики, социологии и права / глав. ред. В. И. Пароль. Таллинн : Русское академическое общество Эстонии. № 10. С. 19-24. 
Коренкова, Н. Е. (2008) К вопросу о совершенствовании системы профессиональной подготовки и повышения квалификации кадров в области физической культуры и спорта // Подготовка кадров для Олимпиады: проблемы и перспективы: Материалы 1-й Междунар. науч.-практ. конф., 13-16 мая 2008 г. / отв. ред. Г. М. Романова. Сочи : РИО СГУТиКД. С. 108-117.

Коренкова, Н. Е. (2012) Психомоторные аспекты психологической безопасности человека // V Съезд Общероссийской общественной организации «Российское психологическое общество» (Москва, 14-18 февраля 2012 г.): науч. материалы. М. : РПО. Т. 2. С. 415.

Коренкова, Н. Е. (2017) К вопросу обеспечения психологической безопасности специалиста в деятельности, осуществляемой в особых условиях // Научное обеспечение психолого-педагогической и социальной работы в уголовно-исполнительной системе: Сборник материалов Всероссийской научно-практической конференции, посвященной 25 -летию со дня образования психологической службы уголовно-исполнительной системы (Рязань, 31 марта 2017 г.) /Под общей редакцией Д.В. Сочивко. Издательство: Академия права и управления Федеральной службы исполнения наказаний (Рязань). С. 591-595

Медведева, Е. В. (2016) Особенности психомоторного и умственного развития у детей младшего школьного возраста : бакалаврская работа. Рукопись. М. 69 с.

Коршунова, Е. С. (2012) Взаимосвязь индивидно-личностных свойств и графологических характеристик почерка у студентов : дипломная работа. Рукопись. M. 58 c.

Киселева, Т. И. (2006) Взаимосвязь психомоторики со стилем личности реагирования на фрустрацию : дипломная работа. Рукопись. М. 56 с.

Калинина, Л. В. (2005) Взаимосвязь графологических характеристик с индивидно-личностными особенностями человека : дипломная работа. Рукопись. М. 46 с.

Савина, Л. А. (2009) Особенности индивидно-личностных характеристик школьников с разными функциональными состояниями : дипломная работа. Рукопись. М. 63 с.

Зотина, Е. И. (2003) Взаимосвязь графологических характеристик с уровнем развития интеллекта (на примере юношеского возраста) : дипломная работа. Рукопись. М. 46 с.

Толкачева, Н. А. (2017) Взаимосвязь адаптивности и психомоторных показателей подростков : курсовая работа. Рукопись. М. 49 с.

Бекетова, А. А. (2017) Графологические особенности почерка лиц с расстройствами психического здоровья : бакалаврская работа. Рукопись. М. 55 с.

Бекетов, А. И. (2017) Использование графологического анализа почерка для оценки динамики признаков агрессии у больных шизофренией : бакалаврская работа. Рукопись. М. 48 с.

Захаревская, Е. А. (2015) Взаимосвязь индивидно-личностных особенностей человека с показателями моторной активности рук : магистерская работа. Рукопись. М. 83 с.

Дата поступления: 20.02.2018 2. 
Коренкова Наталья Евгеньевна - кандидат психологических наук, доцент кафедры общей психологии и истории психологии Московского гуманитарного университета. Адрес: 111395, Россия, г. Москва, ул. Юности, д. 5 . Тел.: 7 (499) 37467-20. Эл. адрес: korenkova75@mail.ru

Korenkova Natalya Evgenyevna, Candidate of Psychology, Assistant Professor, Department of General Psychology and the History of Psychology, Moscow University for the Humanities. Postal address: 5, Yunosti St., Moscow, Russian Federation, 111395. Tel.: +7 (499) 374-67-20. E-mail: korenkova75@mail.ru

\section{Для цитирования:}

Коренкова Н. Е. Разработка проблемы психомоторики на кафедре общей психологии и истории психологии Московского гуманитарного университета [Электронный ресурс] // Научные труды Московского гуманитарного университета. 2018. № 1. URL: http:// journals.mosgu.ru/trudy/article/view/679 (дата обращения: дд.мм.гг.). DOI: 10.17805/ trudy.2018.1.4 